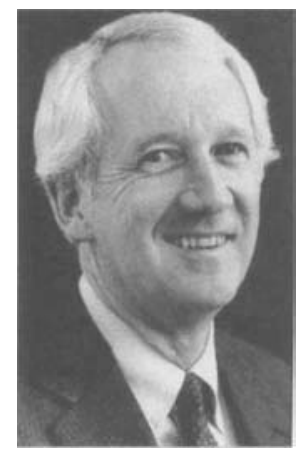

\title{
State fiscal crisis squeezes higher education
}

\author{
WILLIAM W. BAKER, \\ Vice President, University and External Relations \\ UC Office of the President
}

$\mathrm{F}$ or California as a whole and higher education in particular, a political reality of the 1990s has been a lingering fiscal crisis that's eating away at the public investments made by the state during the 1950s and 1960s. These investments in education, roads, water systems and social services provided fuel for California's economic growth and for sustaining a quality of life that's synonymous with the "Golden State."

But California's fiscal crisis is taking its toll.

In the past 5 years, state support for higher education has declined by about $14 \%$, after adjusting for inflation, while the demand for skilled, educated workers continues to grow.

For UC alone, state funding has been cut by $\$ 341$ million during the past 3 years. We've had to cut budgets even further to cope with inflation and other increases in fixed costs.

Our campuses are being squeezed as they lose faculty and staff to layoffs and early retirement programs, and as they absorb funding gaps that cut into the basics - libraries, instructional equipment and maintenance. Throughout $\mathrm{UC}$, there are nearly 5,000 fewer full-time employees today than 3 years ago, a cut of $13 \%$ of the state-funded workforce. Administration has been cut three times more than faculty. Funding for UC building maintenance has dropped so low that deferred projects now total nearly $\$ 350$ million. At the current rate, it will take more than 33 years to eliminate the backlog, assuming no new projects are added.

We've asked students to pay more in higher fees. For those who can't afford higher fees, we're providing more scholarships, grants and loans by setting aside about one-third of the fee increases for financial aid.

The funding picture isn't much brighter for public schools. The Center on Budget and Policy Priorities, a think-tank in Washington, D.C., says that in 1960 , California spent $21 \%$ more per student than the rest of the nation. Now, the state spends $14 \%$ less than the national average. Now, California has the seventh worst high school graduation rate in the country, worse than states with historically low funding for public services such as Mississippi and Alabama.

When it comes to developing infrastructure, California has experienced the worst decline of all 50 states. From 1960 to 1988, California's infrastructure - including roads, schools, sanitation systems, water and other utilities - fell from 3rd in the nation to 36 th.

California's funding crisis goes deeper than the current economic recession. This crisis stems from long-term, structural flaws in California's tax and budget system.

More than $85 \%$ of the state's budget is locked up by the state constitution or by statute to fund welfare, health care, $\mathrm{K}$ through-12 and community colleges and prisons. And the percentage committed to those programs grows each year because expenses grow faster than state revenues. If this continues, by 2000 , nearly all state revenue will go to those programs, leaving nothing for higher education and general state government. If you add the cost of "3-strikes-and-you're-out," the situation defies description.

For the past year, I've been working with the California Business-Higher Education Forum to identify long-term solutions to the state's funding shortfalls. To address the issue of fiscal reform, we appointed a special task force.

The result is five key recommendations including the proposal that California consider major structural changes to its tax base - such as expanding the state sales tax to consumer services and modifying Proposition 13 to be more fair.

The forum also recommended that the state broaden its tax base by gradually extending the sales tax to consumer services. Today most services are exempt from sales tax. Sailing lessons, for instance, are exempt, but a book on sailing is not.

California tax revenues could grow by $\$ 5$ billion if the sales tax were extended to personal and entertainment services. The additional funds could be invested in infrastructure, social services and education, or used to reduce the sales tax rate by as much as $2 \%$.

The rest of the country already is moving in this direction. Forty states tax a larger number of services than California does.

The forum study found that state government has been solving its budget problems by shifting the burden to local governments, particularly county governments. This is not a long-term or stable solution.

The forum made four other recommendations to California:

- Establish clear goals similar to the initiatives it pursued in the 1950s and 1960s such as the Master Plan for Higher Education, the state water project and the interstate highway program.

- Work to improve the performance and accountability of state government.

- Strengthen local governments.

- Continue and expand regulatory reform in the state.

The forum concluded that California cannot maintain a strong economy without adequate investment in public infrastructure and public services, including education. The governor and state legislature have created a Constitutional Revision Commission that is addressing similar concerns. We are working with the commission as well as other public policy groups to help find some answers.

These editorial comments are derived from the California Business-Higher Education Forum report "California Fiscal Reform: $A$ Plan for Action," issued in June 1994. It is available for a nominal fee by calling (510) 987-9100. 